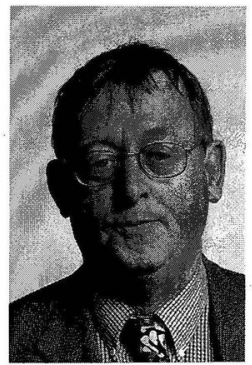

\title{
KNOWLEDGE INTENSIVE \\ PRODUCTION: THE CASE OF \\ THE FURNITURE INDUSTRY
}

\author{
Paul Harris \\ University of Waikato \\ Private Bag 3105, Hamilton
}

\begin{abstract}
New Zealand is currently debating its potential to contribute to what is commonly known as the "knowledge economy". In discussing the knowledge economy, politicians and certain academics tend to reduce it to industries such as information technology and biotechnology. However, both skill and design are forms of knowledge that are incorporated into value-added products such as high quality furniture. Denmark and Italy are two countries that have taken the lead in the export of such products.
\end{abstract}

This paper explores the role of skill and design in the Italian and Danish furniture industry in comparison with developments in the NZ furniture industry.

\section{Introduction}

This paper has a two-fold purpose. First, by using Denmark and Italy as examples, to demonstrate that the furniture industry, and especially its high value added/high quality end, is a knowledge-intensive one and deserves serious consideration in any debate about a knowledge economy. Second, to assess the New Zealand furniture industry in the light of the Danish and Italian examples and to consider to what extent it is capable of emulating them.

\section{The knowledge economy and the furniture industry}

There is a growing global consensus that knowledge is now an increasingly important factor in production and in economic development. It follows that if a nation wishes to remain, or to become, globally competitive, it must construct itself as a knowledge economy. The race to become a knowledge economy has seen nations like Australia, Britain, Canada, and New Zealand adopt policies aimed at achieving this. The European Union has set itself the goal of becoming, by 2010 , "the most competitive and dynamic knowledge-based economy in the world" (Bolkestein, 2000). Even the poverty stricken and war-ravaged state of Rwanda is seeking to become a knowledge economy within 20 years (Miller and Esselaar, 2002).
What is the basis of a knowledge economy? Taking their lead from the OECD (1996), most nations look to the development and growth of high technology and science based industries. The diffusion of information and communications technologies (ICT) and the rate of spending on R\&D are taken as indicants of the degree to which an economy is knowledge based. A New Zealand report cites the percentage of high tech exports and the number of computer science, maths and engineering graduates, per 1000 of the population, as two key indicators for the knowledge economy (Minister for Information Technology Advisory Group, 1999).

The furniture industry does not figure in most estimations of the knowledge economy. It is, according to the OECD (1996), a low technology industry. This characterisation is continued in a subsequent New Zealand study (Walker and Liu, 1998), which also includes it with the wood products sector in the resource intensive group of industries. However, the government's approach to the knowledge economy is a broader one than that found in some other nations and has relevance to the furniture industry in two directions in particular, those of design and skill.

The government has identified three areas in which it intends to concentrate its resources in its pursuit of economic and social development. Two of these are, not surprisingly, ICT and biotechnology, but the third is the creative industries which are seen to include 'design' as one of them (Office of the Prime Minister, 2002). A design industry taskforce was established by Industry New Zealand as part of the innovative New Zealand strategy and it includes in its ranks a representative of 
Formway Furniture, a firm with a recognised reputation for the design qualities of its products (Industry NZ, 2002). The government has also made clear that a drive to a knowledge economy must include raising skill levels as a whole and that the production of scientists, researchers, etc must be complemented by a broad diffusion of skills throughout society (Maharey 2001a, 2001b, 2001c).

Any perception that because furniture is a low-tech industry it is therefore a low-knowledge one is mistaken. In the debates on the knowledge economy, a distinction is normally made between codified and tacit knowledge. The latter is essentially inherent to an individual, the former is capable of being communicated, embodied in material goods, and traded (Maskell, Eskelin et al, 1998, Soete, 2001/2). Expertise in design and skill in production bring both codified and tacit knowledge to the furniture industry. In nations like Denmark and Italy, as shall be discussed, industrial districts also function to promote and disseminate knowledge within the industry and in those nations it is justifiable to class furniture production as a knowledge intensive industry.

\section{Denmark and Italy in the global furniture industry}

The developed nations currently produce almost $80 \%$ of the world's total furniture output within an industry estimated to be worth over $\$ 400$ billion (in this paper, the US definition of a billion as being one thousand million will be used).

(CSIL Milano, 2001). Denmark and Italy are two major producing and exporting nations within the industry, with Italy being the world's leading exporter as measured by value of goods sold. Their output is based primarily on the efforts of small and medium size enterprises that comprise the great majority of their furniture manufacturing firms, although both also have some large firms in the industry.
The Danish furniture industry has enjoyed sustained export growth since the 1970 s. Since that time, its market share for wooden furniture amongst the OECD nations has continued to be at least four times higher than its share of all commodities (Maskell, 1998). The Italian industry has followed much the same pattern of continuous export growth. Although New Zealand furniture exports rose from 2000 to 2001, they are still smaller as a percentage of total sales than they were in 1993, whilst the percentage of the total market taken up by imports has almost doubled in the same period (NZ Furniture Association, 2000). In Table 1 a comparison is made between the two countries and New Zealand in terms of firm size and export performance.

Their vastly superior performance to New Zealand's does not result from any 'natural' factor endowment that gives them an advantage in the furniture trade. Denmark's wooden furniture industry is dependent on softwoods, of which it imports $85 \%$ of its supply. It also imports over $90 \%$ of the machinery and equipment used in its wood processing industry (Maskell, Eskelin et al, 1998). Italy imports $80 \%$ of the wood it uses (CSIL Milano, 1999). Neither is due to the impact of cheap labour. Denmark and Italy each have a higher per capita GDP and a higher level of disposable income per capita than New Zealand (OECD, 2002).

Denmark is similar to New Zealand in many ways. It has a slightly larger population, around 5.3 million people, and an economy in which dairy production plays an important role. Denmark is a small, open, economy, as New Zealand has been only since 1984. Italy is much more heavily populated, but its furniture industry is concentrated in a small number of industrial districts comprising small towns and/or townships that collectively have a population that "does not usually exceed 100,000" (Trigilia, 1992, p.36).

Table 1. Comparative Data on the Furniture Industries of Denmark, Italy and New Zealand

\begin{tabular}{|l|c|c|l|}
\hline & Firm Size* & Export \$ & Trade Balance \\
\hline Denmark & 6 & $\begin{array}{c}7.0 \text { billion } \\
(2000)\end{array}$ & $\begin{array}{l}80 \% \text { of furniture production is exported. Major positive } \\
\text { balance }\end{array}$ \\
\hline Italy** & 4.7 & $\begin{array}{c}19.7 \text { billion } \\
(2001)\end{array}$ & $\begin{array}{l}\text { Exports are } 45 \% \text { of industry turnover. Italy has a } \\
\text { substantial }(\$ 16.6 \text { billion in 2001) trade surplus in } \\
\text { furniture }\end{array}$ \\
\hline New Zealand & 5.3 & $\begin{array}{c}91.8 \text { million } \\
(2001)\end{array}$ & $\begin{array}{l}\text { Exports are } 8.3 \% \text { of total sales, New Zealand imported } \\
\text { \$224.million worth of furniture in 2000-2001 }\end{array}$ \\
\hline
\end{tabular}

* Average number of workers (including employers) per firm

**Average of 9 major furniture industrial districts

Sources:

Furniture Association of New Zealand/Department of Statistics.

Internet sites: Association of Danish Furniture Industries, Federation of European Furniture Manufacturers, Timber and More (2002a), Global Wood

\& Furniture Marketplace Online. 
Table 2: Comparing New Zealand and the Matera furniture producing industrial district

\begin{tabular}{|l|c|c|c|}
\hline \multicolumn{1}{|c|}{ Area } & Number of firms & Number of employees & Exports \$M \\
\hline Matera & 80 & 2000 & 408 \\
\hline New Zealand & 1768 & 9350 & 91.8 \\
\hline
\end{tabular}

Sources:

Furniture Association New Zealand/Statistics New Zealand.

Ministry of Industry, (2001a) and Salvato, for Matera.

Each Italian district specialises in one or a narrow range of products. For example, the Brianza district concentrates on high-end furniture and the Manzano district on wooden chairs. To help us put the New Zealand industry in perspective, it is helpful to compare it to one of smaller Italian districts, Matera, whose speciality is drawing room furniture. It had a very good year for exports in 2000 (Salvato, 2001), and its average firm size is large for the Italian industry. But given the much smaller workforce it has compared to New Zealand, the comparison provides food for thought.

The Danish and Italian industries create a positive balance of trade in furniture and at the same time they create jobs. Their employment impact is also upstream and downstream of the industry. In the Italian case, upstream effects have included the production of equipment and fabrics, and downstream to include transport services, interior design professions and administrative services (Lojacono and Lorenzen, 1998). It would clearly be in New Zealand's interest to be able to replicate such beneficial economic impacts.

To be able to do so, it would also be necessary to learn from the factors that have contributed most to the success of Denmark and Italy. Three of these stand out in particular and each is relevant to the production, application and diffusion of knowledge. They are the input of design expertise, the role of skilled labour, and the effects of a concentration of production in clusters within specialised industrial districts. Each of those factors will next be examined.

\section{Design and skill}

The Danish and Italian furniture industries are known for producing high quality furniture. Danish products are directed towards consumers for whom the "Made in Denmark" label is a sign of quality (Kristensen, 1992). Italian export furniture also tends to focus on the quality conscious, and some of its furniture districts specialise in the high end of the market. Within the district of Brianza, for example, the area of Cantù concentrates on the handicraft production of high quality domestic furniture (Ministry of Industry, 2001b).

Design is one form of knowledge that has been vital in the creation of value and the construction of quality in the industries of both nations. It has been claimed that: "In
Italy and other parts of Europe, the designer is God" (Pine Magazine, August 2001, p.23). More prosaically, an Italian report on industrial design (Poli, 2001) states that: "Il design e, per l'Italia, risorsa strategica di notevole rilevanza economica"- "For Italy, design is a strategic resource of considerable economic importance". Since the end of World War Two, it has been a highly productive resource for both nations.

In immediate post-war Italy, US-influenced designers worked with the larger, export-oriented, furniture companies like Cassina that that were interested in creating modernistic furniture. That impetus led to the establishment, in 1956, of the first professional body for designers, the Association for Industrial Design (Sparke, 1988). The Danes had established a school for furniture design within their Royal Academy of Fine Arts in 1924 and three years later the Guild of Cabinet Makers held its first exhibition of Danish furniture designed by architects (M. Gelfer-Jorgensen, 2002). But it was in the 1950s that Denmark began to gain an international reputation for its furniture design and since then "design has become an integral part of product development" (J. Bernsen, 2002).

In the 1950s, Cassina utilised architects from outside the company as its designers. By the 1990 s it had become a leading player in the Italian upholstered furniture market and employed over 500 workers (Lojacono and Lorenzen). It now draws on leading Italian designers and those from other nations and has an exclusive agreement to reproduce furniture designed by such famous architects of the past as Le Corbusier and Frank Lloyd Wright (Cassina, 2002). The Danish industry also uses local and international architects and designers. Its own furniture designers are often graduates of specialised institutions such as the School of Design operated by the Ministry of Cultural Affairs and which offers a five yearly training period to an annual intake of 120 students (Danmarks Designskole, 2002)

Designers in both nations have developed close working ties to furniture manufacturing. Sparke points out that it was the growth of the Italian industrial districts in the 1970 s that fuelled "the continued high profile of design and the sustained commitment to high quality in the furniture industry" (1988, p.205). A contemporary Italian designer has commented that within the furniture districts it is natural for young designers "to grow into furniture design". (A. Citterio, cited in Sokol, 2002). Nor are the services of designers restricted to large-scale Italian 
firms. In the Poggibonsi region, for example, end producers firms - whose average size is between 50 and 60 employees - commission new design for their products (Bambi, 1998, p.62).

Firms with a reputation for high quality products value, and make effective use of, craft skills as well as design expertise. The Danish firm Skovby has won several awards for its design, but it also stresses that "craftsmanship is our driving force" (Skovby, 2002). A number of leading Danish designers started their working careers as crafts people such as cabinet makers and upholsterers. The Danes identify the "vibrant tradition of craftsmanship" and the interplay of craft workers (and manufacturers) with designers as crucial to the postWorld War Two establishment of the industry's reputation for quality (Association of Danish Furniture Industries, 2002).

It has been estimated that a majority of the male workers in the Danish furniture industry are formally skilled (Kristensen, 1992). A system of technical schools underpins the craft tradition in the Danish furniture industry. The first technical school specialising in furniture production skills was established in 1964. The small-firm sector of the industry has a high rate of firm turnover (failures and new start-ups) and it is normally skilled workers, such as carpenters and cabinet-makers, who begin new firms (Maskell, Eskelin et al, 1998). The existence of a cadre of trained workers, ready to move into new avenues as market conditions dictate, helps to explain the success of the Danish furniture manufacturing industry (Kristensen, p. 148).

Similarly, the ability of Italian furniture firms to manufacture high quality products has been seen to rely on the use of highly skilled workers (Lojacono and Lorenzen, 1998). Italy has long-established artisanal traditions in all its industrial districts (Trigilia, 1992), and the availability of artisanal skills have been seen as necessities in the final phrases of production of high-end market goods (Bambi, 1998, Ministry of Industry, 2001b). Firms aiming at such markets are especially keen to draw consumer attention to the artisanal input into the production process. For instance, Formitalia, in advertising its furniture products, takes pains to point out that the "modern methods" it uses in its factories never prevail over the methods which are "taught by the old artisans to the young" (Formitalia, 2002).

The craft tradition within the Italian furniture districts is fostered and furthered by a number of supportive institutions such as the National Association of Artisans (Kristensen, 1992). At all levels of the production process, the construction of industry-relevant codified knowledge depends on the availability and quality of training and tertiary institutions. For instance, a threeyear degree course in technology and the wood industry established in 1995 in Vittorio Veneto has focussed successfully on meeting market demands for skilled, technical and managerial workers in the furniture (and wood) industry (Timber and More, 2002b). In Manzano, the local technical training institute has worked to upgrade labour force skills to respond to the requirements of new production technologies (Unido, 2001b).

\section{Industrial districts}

Furniture production in Denmark is concentrated in a number of districts in the area of West Jutland, whereas the furniture industry districts of Italy are dispersed throughout the country. National and geographical differences in location are far less important than the features the industrial districts share in common. Farinelli (1996 p.1.) states that the strength of an industrial district lies in its "clustering and cooperative competition, together with the industrial atmosphere created by a mix of competence, skills, entrepreneurial ability, trust and a sense of community, which together open up the possibility of gains in terms of efficiency and flexibility which individual producers can rarely attain working alone".

Cooperation operates at a series of levels: extra-district, within the district, between firms, and within firms. Cooperation between individual firms and within single firms is less institutionalised and has a number of bases, of which contractual relationships are one. Many Danish firms have a long-term relationship with a single major customer and/or a single major supplier that encourages the exchange of business information (Maskell, 1998). Firms that occupy different positions in production chains can be linked by contracts but they also collaborate over questions of design and technology. Additionally, in the Danish case, firms that win contracts to produce for the final market often employ their erstwhile rivals for the contract as subcontractors for part of the order. This has been described as the mechanism by which "many of the entrepreneurs learnt their ways of doing business"(Kristensen, 1992 p. 151).

Owners of firms in smaller localities can also be neighbours and have informal social contacts with their fellow owners. In West Jutland, the existence of cooperative relationships between small firms ensures that when skilled workers set up new enterprises, their skills are not lost to their former employers (Lorenzen, 1997). Many firms also share kinship ties due to the number of family firms, and Italian artisanal firms in particular tend to be family businesses (Lazerson, 1993).

These ties can lead to inter-firm and intra-firm continuities: this is "a story of fathers, brothers and sons, masters and apprentices..."says Kristensen (1992, p.149) of Danish furniture makers. In the Italian industrial districts, employers who are connected by family ties to employees have proved willing to finance them in attempts to become entrepreneurs. Conversely, the family acts as a cushion for failed entrepreneurs who must become employees again (Weiss, 1989, Storper, 1995).

Intra-firm relationships between employers and workers appear to be productive and conducive to creating 
cooperation and trust, as evidenced by the relative lack of industrial conflict in either the Danish or the Italian furniture industries. The Danish furniture workers are organised in unions, are covered by collective agreements and enjoy the normal (Danish) high standard of living (Maskell, Eskelin et al, 1998). Skilled labour in the Salling furniture district is in high demand and is supposedly higher paid than in surrounding areas (Lorenzen, 1997). Employers have concentrated on "competitive strategies aimed at dynamic innovation, quality and design consciousness" rather than cost cutting (Maskell, Eskelin et al, 1998). Unionisation rates vary between the Italian industrial districts but the unions have been supportive of the local industries and have accepted the flexible deployment of labour within and between firms (Trigilia, 1992).

In the Taylorist/Fordist mode of organising work, knowledge was a battleground between management and labour, and employment relations were essentially distrustful. In the more cooperative and trust-based workplaces of the industrial districts, where the "rigid divisions between mental and manual labour" as found "in the Fordist model" of production (Kristensen, 1992, p.124) have been overcome, then workers are much readier to share knowledge with management, and vice versa. Equally as supportive of knowledge are the other forms of cooperation discussed. Using the furniture district of Salling as a case study, Lorenzen (1998) comments on the sharing of information on technical opportunities, user needs and producer capabilities at meetings of the local producers' association, as well as at informal social gatherings. He goes on to argue that localised tacit knowledge and localised learning processes contribute to trust relationships between the producers.

More formal mechanisms for generating and sharing knowledge exist at the district or extra-district level. In 1989, following a seminar on a particular Italian industrial district, the Danish government decided to initiate a programme to develop small firm networks. One result of this programme was that furniture industry firms that formed networks went on to pool resources which made it easier for them to buy advanced equipment, fund export marketing ventures, hire designers, and develop work processes (Shukla, no date). The decision to learn from Italy was a reflection of the fact that its industrial districts had a history of creating formal mechanisms of cooperation.

Amongst the longer established of the formal mechanisms are the real service centres that focus on issues such as training, export promotion, quality certification and product promotion. These services are highly customised to meet the needs of individual districts and there are currently over 130 of them (Unido, 2001a).

A collective response to the need to find and exploit new markets for the chair manufacturers of the Manzano industrial district led, in 1983, to the establishment, by manufacturers and a local chamber of commerce, of the Promodesia company. Promodesia appears to have succeeded in alerting manufacturers to the requirement of new markets around the world (Clara, 1998). The regional government of the area in which Manzano is located also helped fund a technical centre to enable manufacturers to adapt their products to meet the safety requirements of export markets (Unido, 2001b).

In the pursuit of excellence in design, the town of Cantù has established the Centro Legno Arredo Cantù (Cantù Centre for Wooden Furnishings). The Centre (CLAC) has the support of local and regional government, chambers of commerce and the three Italian national trade union centres. Amongst its activities, CLAC has established a projects bank aimed to keep artisanal firms up to date with the latest designs and to promote closer relations between those firms and the designers (CLAC, 2002). In the Poggibonsi district the Experimental Furniture Centre (Centro Sperimentale Del Mobile, normally known as CSM) works to "reproduce that mix of technical-productive and managerial capacities which are necessary for the survival and development of the local productive system" (Bambi, 1998, p.66). CSM is currently cooperating with other industry organisations and local bodies in a project aimed at promoting innovation and improved managerial and technical skills in the industry within the Tuscana (Tuscany) region as a whole (CSM, 2002).

These extra-district and district level forms of cooperation address themselves to issues such as design, marketing, skills and training. But they leave unanswered questions about how predominantly small firms can generate relevant knowledge without benefit of the research expenditures and specialised R\&D departments of large firms. Kristensen (1992) has argued that inter-firm collaboration compensates for the lack of internal $\mathrm{R} \& \mathrm{D}$ departments in the small firm. Salvato (2001) builds on this by emphasising, as Lorenzen (1998) has done, the role of localised know-how.

Salvato argues that: "Even if innovation is difficult for individual firms, this is not true for the district as a whole. With the incremental creation of know-how, every firm frees positive externalities which can be appropriated by others, especially when there is physical proximity and cooperation. Therefore, even with very modest investments in research, increasing returns in output can be achieved in these districts, through the appropriation of technological externalities which derive from the incremental up-grades obtained in individual firm" (2001, p.6).

\section{The New Zealand furniture industry and knowledge}

The New Zealand furniture industry has followed a different historical trajectory than those of Denmark or Italy. Within the OECD, in 1970 only Portugal was ranked lower than New Zealand on an index of furniture 
consumption that measures production plus exports and minus imports. By 1992 our ranking out of 18 nations was 16th equal with Spain (Maskell, Eskelin et al, 1998). As has been seen, our total furniture exports are not only very small by international standards but they are also worth a lot less than our imports.

Part of the reason for this is that New Zealand (contra Denmark) developed as a small, closed, economy. Our manufacturing industries, including furniture, were sheltered behind walls of tariff protection and import controls. Furniture producers had thus far less incentive to be innovative and industrial design was not seen as an industry priority. As one commentator put it, in the New Zealand case "manufacturers and designers often make uneasy bedfellows" (McLean, 1994, p.15). We did have a tradition of producing skilled workers, but the changes to apprenticeship training and employment relations law in the 1990 s led to a shortage of skilled workers that is still being felt throughout industry. Nor did we ever produce West Jutland or Italian-style industrial districts.

The removal of tariffs saw the industry being squeezed in two directions at once, by low cost imports from Asia and high quality and high priced ones from Europe (New Zealand Furniture Exporters, 2000). It would be impossible to compete with leading Asian exporters such as Indonesia or China on a cost basis, especially given their very cheap labour. For example, in 1999, average wages in New Zealand were over 11 times as high as those of China (Import Administration, 2001). Instead, the industry has decided to focus on becoming a high quality exporter, which in turn means it must become a knowledge-intensive one.

The importance of design has been recognised by the industry and "encouraging and facilitating the use of furniture designers" is one of the objectives of the Furniture Association of New Zealand (FANZ), the industry's national body (FANZ, 2002). Individual New Zealand firms are also making progress on the design front. In the household furniture market, Tauranga firm Design Mobel prides itself the role design has played in its success. The company points out that "In the last four years alone we have won eighteen major design awards"(Design Mobel, 2002). To add to its image as a quality producer, the firm has also gained ISO 14001 accreditation for the environmental standards of its activities and products and an ISO 9001 accreditation for its production systems. In addition, it uses a high quality material, rimu, for its products.

Formway Brendon is now New Zealand's leading exporter of steel furniture, specialising in office systems. Its first major export market was Australia and in 1999 began to approach the US market by appearing at a furniture exposition in Chicago (New Zealand Herald, 1999). It won two design awards at that exposition and later won a third US award. By 2000 it was employing 20 people (from a staff of around 150 ) solely on design and the growing US demand for its products was seen as exemplifying the case that "well managed design products actually reduce risk"(Prodesign, 2000). It has since gone on to win further Australian, New Zealand and US design awards (Formway Brendon, 2002). It is its track record in design and in exporting that makes it understandable why a firm representative was invited to join the Industry New Zealand working group on design.

The importance of furniture to design and of design to furniture is becoming more widely recognised. For instance, furniture is part of the course content for the Bachelor of Industrial Design offered by Massey University and is also included as one of the topics addressed in the material on industrial design the Career Services publish for job seekers (Career Services, 2002). The need to increase skill levels and also to increase the pool of skilled labour on which the industry can draw has also been acknowledged. The Furniture Industry Training Organisation (FITO) now has 603 apprenticeship trainees on its books (FITO 2002a.). FITO is also cooperating with Workbase and Formway Brendon in a scheme whereby 16 mainly Pacific Island employees of the firm are having their English language skills upgraded as part of their work towards obtaining a national certificate in steel furniture making (FITO 2001).

An established firm like Danske Mobler can claim that its wooden furniture is made by craftsmen in Scandinavia and New Zealand (Danske Mobler, 2002), but within New Zealand there are still gaps in the industry's skill requirements. A FITO representative who is also an upholstery expert has complained about "an acute shortage of skilled workers in the trade" and has argued that companies are not providing adequate training for workers (FITO, 2002b). There is also a gender and ethnic gap; only a small minority of FITO trainees are women and Maori and Pacific Island trainees are also minority groupings (FITO, 2002c). However, there is nothing intrinsic to furniture production to prevent its skilled workforce becoming more representative of our society.

It is more challenging to try to emulate the Danish and Italian experience of knowledge-rich industrial districts. They evolved over time in specific circumstances and cannot simply be copied wholesale. But moves can be made to apply some of their features (just as the Danes applied Italian experiences of networking). A positive step in that direction was first taken when, in 1998, the industry was involved in a strategic planning mission orchestrated by TradeNZ and which included trying to establish overseas niche markets (New Zealand Pine International, May/June 1998). From this initiative the New Zealand Furniture Exporters group was developed.

In its submissions on the possible policy directions of the then new Industry New Zealand, the group called for cooperative partnerships of exporting companies (clusters), with integrated participation of suppliers, government and industry organisations and also for the fostering of trust among cluster members. It went on to point out that it had "facilitated a successful USA market entry strategy for a cluster of several New Zealand furniture 
manufacturers" (New Zealand Furniture Exporters, 2000).

The cluster organisation promotes itself as Furnz (Furniture New Zealand) and comprises Danske Mobler, Europlan, Formway Brendon, D.A. Funnell's, Furnware, Goode Industries, Lundia and Scott Panel \& Hardware (a Fletcher subsidiary). Based in Maryland, it advertises itself as a "new concept in collective marketing" (Furnz, 2002) New Zealand Furniture Exporters is also supporting the development of a Christchurch based cluster of six furniture firms that is intended to focus on exporting high quality furniture, primarily to the Australian market initially (New Zealand Furniture Exporters, 2000).

These forms of cooperation are a long way from being small-firm centred forms of industrial districts. But they do encourage a collective use of knowledge amongst their participants. They also build on the cooperation that has already taken place between State bodies like Industry New Zealand, industry organisations and individual firms. Together with greater use of design and an increase in workforce skill levels, they help facilitate the development of the industry as knowledge-intensive one that can compete at the quality end of world markets.

\section{Conclusion}

If we define the knowledge economy and knowledge industries too narrowly we risk marginalising all those industries, and their employers and employees, that are not found in the 'trendy' ICT, biotechnology and high R \& D sectors. As the Danish and Italian examples have shown us, globally successful furniture industries producing high quality goods are extremely knowledge intensive. Such industries also generate export earnings, a positive industry balance of trade, a demand for professional and craft skills, and productive and decently paid jobs. These are desirable outcomes that New Zealand would benefit from achieving.

The local industry is now more focussed on design and is supporting efforts to produce an appropriately skilled workforce. We lack the industrial district structure that is such a valuable knowledge base and knowledge source in Denmark and Italy, but efforts are being made to encourage greater cooperation between firms in the industry in the effort to reposition it as an exporter of high quality products. The New Zealand furniture industry has the potential to develop as a (relatively) low tech but knowledge intensive motor of economic growth. Continued cooperation between relevant State bodies, industry organisations, producer firms, and other interested parties will assist in achieving that goal.

\section{References}

Association of Danish Furniture Industries. (2002). 'Facts about the Danish furniture industry'.Located at: http://www.danishfurniture.dk/danishfurniture.

Bambi, G. (1998). 'The evolution of a furniture industrial district. The case of Poggibonsi in Tuscany.' In: M. Lorenzen (ed.) Specialisation and Localised Learning, pp.59-70. Copenehagen: Copenhagen Business School Press.

Bernsen, J. (2002). ). 'Denmark - Culture-Applied Arts and Design-Industrial Design'. Located at: http://www.um.dk/english/danmmark.

Bolkestein, F. (2000). 'The follow-up to Lisbon building a knowledge-driven economy in Europe.' Located at:

http://europa.eu.int/comm/internal market/en/speeches/sp ch312.htm.

Career Services. (2002). "Kiwi Careers. Industrial and Interior Design.' Located at: http://www.careers.co.nz/industry/i12_con/i12aed es.htm.

Cassina. (2002). 'Cassina Historical Profile'. Located at: http://www.cassina.it/story.htm

CLAC (2002) "The "Projects Bank" for artisans and industries involved with furniture and furnishings". Located at:

http://www.clac00.it/eng/iservizieng/bancaprogettieng/ba ncaprogettieng

Clara, M. (1998). 'Promosedia: Marketing SupportFurniture'. Milano: Unido/Italy.

CSIL Milano (1999). 'What are the reasons for the success of the Italian furniture industry?' Located at:

http://web.tin.it/csilfurniture/WorldFurniture/art99 lart15a99.htm

CSIL Milano (2001). 'The World Furniture Market'. Located at:

\section{http://www.csilmilano.com/newsletter/N99art.html}

CSM (2002). ' Casa Toscana: a synergic action'. Located at: http://architettura.supereva.it/casatoscana/Consorzi otoscana.htm

Danmarks Designskole. (2002). 'Welcome to Danmarks Designskole'. Located at: www.danmarksdesignskole.dk December, p.15.

Dansk Mobler. (2002). 'Danish Design Furniture'. Located at: 
http://www.danskemobler.co.nz/danishdesign.htm.

Design Mobel. (2002). 'Achievements'. Located at: http://www.designmobel.co.nz/.

Farinelli, F. (1997?). 'Networks of firms confronting the challenge of globalisation: The Italian experience'. IPTS Report 7. Located at

http://www.jrc.es/iptsreport/vol07/english/Inn2E076.htm

Federation of European Furniture Manufacturers. (2000). 'The EU Furniture Industry'. Located at: http://www.ueanet.com/outlook.htm.

FITO. (2001). 'Back to school's pretty cool'. Fito Newsletter, December, 2001. Located at: http://www.fito.co.nz/news/news_200112.htm.

FITO (2002a). 'Apprentice numbers climb beyond 600.' Fito Newsletter, August, 2002. Located at: http://www.fito.co.nz/news/news 200208.htm.

FITO. (2002b). 'About Turner for trade'. Fito Newsletter, August, 2002. Located at: http://www.fito.co.nz/news/news_200208.htm.

FITO. (2002c). 'Statistics'. Located at: http://www.fito.co.nz/intro/statistics.htm.

Formitalia (2002). Show room. Located at http://www.formitalia.it/showroom/welcome/html.

Formway Brendon. (2002). 'Awards'. Located at: http://www.formway.co.nz/us/awalrds.htm.

Furniture Association of New Zealand. (2002). 'Association Profile'. Located at: http://www.fanzweb.org/profile.html.

FURNZ (2002). 'Welcome'. Located at: http://www.furnz.com/cgi-bin/furnz.storefront.

Gelfer- Jorgensen, M. (2002). 'Denmark - CultureApplied Arts and Design'. Located at: http://www.um.dk/english/danmmark.

http://www.dk-designskole.dk/uk_version/index/htm.

Global Wood \& Furniture Marketplace Online. (2002). 'Furniture Market Dynamics in Italy.' Located at: http://www.globalwood.org/news/b061103.htm.

Import Administration. (2001). '1999 Income Data'. Located at: http://ia.ita.doc.gov/wages/99wages/99wages.htm.

Industry NZ. (2002). 'Design Industry Taskforce Members'. Located at:

http://www.industrytaskforces.govt.nz/design/me mber.html.

Kristensen, P. H. (1992). 'Industrial districts in West Jutland, Denmark'. In: F. Pyke and W.
Sengenberger (eds.) Industrial districts and local economic regeneration, pp.122-173. Geneva: International Labour Organisation.

Lojacono, G. and Lorenzen, M. (1998). 'External economies and value net strategies in Italian furniture districts.' In: M. Lorenzen (ed.) Specialisation and Localised Learning, pp.71-94. Copenehagen: Copenhagen Business School Press.

Lazerson, M. (1993). 'Future Alternatives of Work Reflected in the Past:Putting-Out Production in Modena'. R. Swedberg (ed.) Explorations In Economic Sociology, pp.403-427. New York:Russell Sage Foundation.

Lorenzen, M. (1997). 'Knowledge-Guided Action: Stability Of Knowledge And Patterns Of Cooperation Amongst Furniture Producers In The District of Salling, Denmark'. Academy of Entrepreneurship Journal, Volume 3, Number 1, pp.57-81.

Lorenzen, M. (1998). “ A "higher-order" knowledge base for trust'. In: M. Lorenzen (ed.) Specialisation and Localised Learning, pp.143166. Copenehagen: Copenhagen Business School Press.

Marahre, S. (2001a). 'Introduction'. Moving Forward: Skills For The Knowledge Economy, Wellington: Office of the Associate Minister of Education.

Marahrey, S. (2001b, 7 August). 'Industry decisions in tune with knowledge wave'. Wellington: Office of the Associate Minister of Education

Marahrey, S. (2001c, 16 October). 'Catching the Skill Wave: The Importance of Vocational Learning in a Knowledge Economy'. Wellington: Office of the Associate Minister of Education

Maskell, P. (1998). 'Localised low-tech learning in the furniture industry.' In: M. Lorenzen (ed.) Specialisation and Localised Learning, pp. 33-55. Copenehagen: Copenhagen Business School Press.

Maskell, P., Eskelin, H., Hannibalson, I., Malmberg, A., Vatne, E. (1998). Competitiveness, Localised Learning And Regional Development. Routledge: London/New York.

McLean, V. (1994). 'Pining For Design', New Zealand Forest Industries,

Miller, J. Esselaar, P. (2002). 'Rwanda Seeks To Move From Agriculture To Knowledge In 20 Years.' Located at:

http://www.balancingact-africa.com/news. 
Minister for Information Technology Advisory Group (1999). The Knowledge Economy. Wellington: Minister for Information Technology.

Ministry of Industry. (2001a). 'Brief Overview of Major Industry Sectors'. Located at: http://www.minindustria.it/Gabinetto/Seg.

Ministry of Industry. (2001b). 'Italy's Major Industrial Districts'. Located at: http://www.minindustria.it/Gabinetto/Seg.

New Zealand Furniture Exporters Inc (2000). 'Submission to Government'. Located at: http://www.nzfurniture.com/Newsletters/May2000 government.html.

New Zealand Herald (1999, 6 October). 'Formway heads to US'. Located at http://www.nzfurniture.com/News/news_usa head stousa.html.

New Zealand Pine International (1998). 'The Way Back For NZ Furniture'. May/June, p.12.

OECD. (1996) 'The Knowledge - Based Economy'. Paris:OECD.

OECD. (2002). 'Basic Structural Statistics 2002'. Located at: OECD M0009091 PDF.

Office of the Prime Minister's Department. (2002). 'Growing An Innovative New Zealand'. Wellington: Office of the Prime Minister's Department.

Pine Magazine. (2001). 'Design or Die'. Issue 40, August-September, p.23.

Poli, M. (2001). 'Economia del Design'. Located at: http://www.clac00.it/eng/chisiamoeng/cartinaeng/c artinaeng.html.

Prodesign (2000, August/September). 'The Knowledge Economy and Design'. Located at http://www.nzfurniture.com/News/news_usa_kno wledge.html.

Salvato, C. (2001). 'Evolutionary patterns of successful district companies. Lessons from Italian industrial districts'. Located hitp://www.wbigf.org/Milan.

Shukla, M. (No date). 'Turnaround of Danish Economy:

The Power of Networks'. Located at: http://www.geocities.com/madhukar shukla/1DE NMARK.html

Skovby Mobelfabrik A/S. (2002). 'About Us - History'. Located at: http://www.skovby.com.
Soete, L. (2001/2). 'ICTs, knowledge work and employment The Challenges to Europe'. International Labour Review, Vol.140, Number2, pp.143-163.

Sokol, D. (2002). 'Why Can't We Be More Like the Italians?' Located at:

http://www.metropolismag.com/html/conferences/ icff 2002/icff italseminar 05212002.html.

Sparke, P. (1988). Italian Design. London: Thames and Hudson.

Storper, M. (1995). 'Boundaries, Compartments and Markets: Paradoxes of Industrial Relations in Growth Pole Regions of France, Italy, and the United States'. In S. M. Jacoby (ed.) The Workers of Nations, pp.155-181. New York and Oxford:Oxford University Press.

Timber and More (2002a). 'Furniture Picks up for the Autumn'. Located at: http://www.timberandmore.com/news.

Timber and More. (2002b).'Wood Technology'. Located at: http://www.timberandmore.com/news/newsdettagl io.asp.

Trigilia, C. (1992). 'Italian industrial districts: Neither myth nor interlude'. In: F. Pyke and W. Sengenberger (eds.) Industrial districts and local economic regeneration, pp.33-47. Geneva: International Labour Organisation.

Unido (2001a). 'The Italian Experience of Industrial Districts.' Located at: http://www.unido.org/doc/331114.htmls.

Unido (2001b). 'Manzano Cluster Profile'. Located at: http://www.unido.org/doc/331104.htmls.

Walker P., Liu, J. (1998). 'A Profile of New Zealand's High Technology Competitiveness in Manufacturing Production and Trade'. Wellington: Ministry of Research, Science \& Technology.

Weiss, L. (1989). 'Regional Economic Policy In Italy'. In C. Crouch and D. Marquand (eds.) The New Centralism, pp. 109- 124. Oxford: Basil Blackwell.

Whitford, J. (2001). "The decline of a model? Challenge and response in the Italian industrial districts'. Economy and Society, Volume 30, Number 1, pp.38-65.

World Furniture Online. (2001). 'Italy: A Touch of Classic'. Located at: http://www.worldfurnitureon line.com/data/ html. 